\title{
Autoficción y decadencia: un diálogo con la escuela buraiha japonesa, en "Manos de diamante" de Andrés Felipe Solano
}

\section{Autofiction and Decandence: A Dialogue with Japanese Buraiha School, in "Manos de diamante" by Andrés Felipe Solano}

\section{DOI: $10.32870 /$ mycp.v11i31.770}

\author{
María Claudia Macías ${ }^{1}$ \\ Gerardo Gómez Michel ${ }^{2,3}$
}

\begin{abstract}
Resumen
En este artículo se examina el cuento "Manos de diamante" de Andrés Felipe Solano, analizando la configuración del diálogo entre el narrador autobiográfico y el concepto de decadencia de la escuela japonesa buraiha, mediante el cual se estructura una narrativa del yo en confrontación con los signos de los tiempos de la modernidad actual. Se revisa, primeramente, la trayectoria y el contexto histórico de los escritores buraiha para comprender, en un segundo momento, cómo el autor colombiano construye en el relato un pacto ambiguo de lectura que transita entre una ficción al estilo buraiha y una crónica de la deriva existencial del narrador-autor. Finalmente, se expone de qué manera los elementos propios de la autoficción permiten revelar en el cuento la desintegración del yo y la deriva identitaria en nuestra época.
\end{abstract}

Palabras clave: Buraiha, decadencia, autoficción, pacto ambiguo de lectura, desintegración del yo.

\begin{abstract}
This article examines the short story "Manos de diamante" by Andrés Felipe Solano, pointing out the dialogue constructed between an autobiographical narrator and the concept of decadence of the Japanese school of the buraiha, which constitute a oneself-writing in confrontation with the modernity signs of our time. First, the trajectory and historical context of the buraiha writers are reviewed to understand, in a second moment, how the Colombian author configures an unstable reader-writer pact in the story that moves between a buraiha-style fiction and the chronicle of the author-narrator's existential drift. Finally, it is exposed how these elements of the autofiction genre allow the story to reveal the self-disintegration and the loss of identity in our present times.
\end{abstract}

Keywords: Buraiha, decadence, autofiction, readerwriter pact, self-disintegration.

Artículo recibido el 25 de abril de 2021 y dictaminado el 04 de junio de 2021.

1. Seoul National University, profesora afiliada del Instituto de Estudios Latinoamericanos (SNUILAS). 307-1 Building \#3, 1 Gwanak-ro, Gwanak-gu, Seúl, República de Corea 08826. orcID: https://orcid. org/0000-0002-6602-9135. Correo electrónico: maciascl@snu.ac.kr

2. Busan University of Foreign Studies. Geumjeong-gu, 485-65. Busan, República de Corea. ORCID: https://orcid.org/0000-0002-9628-0750. Correo electrónico: palinuromx@gmail.com

3. La colaboración de Gerardo Gómez Michel para esta investigación se realizó gracias al apoyo de la Fundación Nacional para la Investigación de Corea y el Ministerio de Educación de la República de Corea (NRF-2018S1A6A3A02081030). 


\section{Introducción}

El escritor colombiano Andrés Felipe Solano (Bogotá 1977), radicado en Corea del Sur desde 2012, ha desarrollado su carrera literaria principalmente a partir de dos géneros, la narrativa de ficción y la crónica. De sus tres novelas: Sálvame, Joe Louis (2007), Los hermanos Cuervo (2013), Cementerios de neón (2016), y sus tres crónicas: Salario mínimo. Vivir con nada (2007; 2015), Corea, apuntes desde la cuerda floja (2014) y Los días de la fiebre. Corea del Sur, el país que desafió al virus (2020), la mitad de ellas —las últimas publicadas - tiene como tema central ese país asiático en donde vive con su esposa coreana desde hace nueve años. Su labor literaria ha venido construyéndose sobre los ejes narrativos de un acercamiento in situ de la realidad actual y sus efectos en la sociedad, como en Los días de la fiebre, donde hace la crónica de los primeros tres meses de la pandemia de COVID-19 en Corea; de la recreación histórica desde la trinchera de la ficción con su lúcida representación de los callejones oscuros de la cooperación entre Colombia y Corea del Sur durante la guerra de 1950-53 y los posteriores entresijos a causa de la Guerra Fría, en Cementerios de neón, y el de su propia experiencia como migrante latinoamericano en Asia en una época que desvela cada vez más las falsas promesas de la euforia globalizadora de finales del siglo xx que prometía la integración y la desaparición de las fronteras nacionales, en Corea, apuntes desde la cuerda floja.

En este artículo nos interesa explorar un cuento de Solano donde se crea una intersección de los ejes narrativos que hemos señalado. Se trata de "Manos de diamante", publicado primeramente en japonés e inglés, ${ }^{4}$ por la revista Granta en su volumen especial sobre Japón de 2014, con el título "Pig Skin" (Solano, 2014a). Una tercera versión revisada por el autor apareció en la revista Universo Centro (Solano, 2018), que el autor propone como definitiva y que será nuestro corpus de estudio. El relato cuenta la historia de Andrés, un escritor colombiano que conoce a un misterioso detective coreano en un viaje en ferri entre Busan y Osaka que ha ganado su esposa coreana en un sorteo. El viaje entusiasma al protagonista por su deseo de conocer el entorno de los escritores decadentes de la escuela buraiha, a quienes planea hacer una especie de homenaje con una juerga surtida de alcohol y sexo. El proyecto

4. Nick Caistor lo tradujo al inglés del original en español (Solano, 2014a, p. 127), publicado posteriormente en la revista Buen Salvaje: "Granta lo ha publicado en inglés y japonés, nosotros lo traemos en español. Un relato genial de Andrés Felipe Solano” (Solano, 2015, p. 2). 
de emular a los escritores japoneses en su decadencia y libertinaje no llega a consumarse -el relato termina cuando desembarca en Osaka-, al verse relegado por la obsesión que le causa el detective que, insólitamente, conoce bien la historia de los buraiha.

El narrador-protagonista, después de su encuentro con el misterioso personaje, irá alejándose de la conexión con su vida común; la esposa, por ejemplo, aparece furtivamente en el relato y tiene mínima incidencia en las acciones, para centrarse en sus esfuerzos por saber más de la historia del detective que fue agente del Servicio de Inteligencia de Corea y al que incluso ayuda con un supuesto caso que investiga en el ferri donde viajan. En la confusión del desembarco en Osaka, el protagonista pierde de vista al detective, del cual no vuelve a saber más; pero, como afirma en el presente de la narración desde donde cuenta su historia, el narrador que también es escritor propone que le debe todo a ese hombre que lo inspiró para escribir una novela homónima del cuento que ha logrado buena fama. La obsesión por el detective llega a tal grado que, al final del relato, el narrador-escritor sugiere una espiral borgeana donde su propia identidad parece diluirse en la de un personaje dentro de una ficción del detective, que quizá era "el último de los buraiha" (Solano, 2018, p. 23, citaremos por esta edición).

\section{La autoficción como ingreso a la modernidad}

En este cuento, Solano intersecta las líneas de algunas de sus obras. Por un lado, tenemos un narrador-protagonista que se identifica con el nombre del autor y su nacionalidad, además de la circunstancia de su matrimonio mixto y su profesión como escritor, como aparece en sus crónicas. Por otro lado, el personaje coreano y la referencia directa a la escuela buraiha explora un espacio narrativo que alude a la época de la posguerra en Japón y a la Guerra Fría en Corea del Sur, hasta llegar al presente en que configura al protagonista como migrante en un espacio alienado en el que vaga hasta cierto punto a la deriva. Aquí, se vuelve significativo el motivo del viaje en barco que es donde se desenvuelve la mayor parte del relato. En este sentido, el análisis que proponemos considera dos hilos conductores. En primer lugar, tomando como base el concepto de autoficción, término acuñado por el escritor francés Serge Doubrovsky (2001) refiriéndose a su propia novela Fils (1977) que, como explica Julia Musitano, se trata de un "género paradójico por excelencia, que vacila entre dos mundos, el de la autobiografía y la novela” (2016, p. 104); 
más adelante, siguiendo a Gasparini, Musitano amplía que "la autoficción se presenta como el signo de un progreso que permite el ingreso de las escrituras del yo a la modernidad" (2016, p. 108). Manuel Alberca, quien ha estudiado este concepto en relación con la literatura latinoamericana, explica que para Vincent Colonna, reconocido teórico que ha buscado delimitar las características de este género literario híbrido, "una autoficción es una obra literaria en la que el autor se inventa una personalidad y una existencia, conservando su identidad personal, bajo su verdadero nombre" (Alberca, 2006, p. 118). El relato de Solano permite la entrada al texto por esta vía, la promueve con las coincidencias premeditadas de nombrar al narrador-protagonista Andrés, su oficio de escritor, con esposa coreana y nacionalidad colombiana. Sin embargo, los fines de esta estrategia discursiva no apuntan a cumplir con los requisitos del género para simplemente llevar al lector al terreno de la ambigüedad en el pacto de lectura propio de la autoficción, sino a una más sutil y significativa sugerencia sobre las posibilidades de la escritura del yo y su relación con el referente extratextual del mundo que rodea al autor.

En segundo lugar, luego de abrir el acceso a través de la técnica de la autoficción, Solano tiende otra vía por la que el lector puede circular por su relato, mediante el diálogo que entabla con el concepto de decadencia que desarrollaron los escritores buraiha de la posguerra japonesa, a los que directamente se refiere el protagonista como motivo percutor de la trama narrativa y su desenlace. Como se verá con detalle en el apartado siguiente, los escritores buraiha promovieron y vivieron desde el filo del libertinaje y la decadencia como una forma de protesta hacia la normalización en la posguerra de una sociedad japonesa derrotada. En estos escritores existía un fuerte amalgamamiento entre su vida real y su producción, que bien podríamos considerar como cercano a la autoficción, ya que en ambos casos buscaban sacudir las conciencias conservadoras de los japoneses de ese momento. No obstante, la parte más escandalosa de la postura buraiha fue la que tuvo más impacto, incluso ellos mismos aceptaban ser señalados como libertinos, lo que en realidad no alcanzaba a dimensionar el sentido de su rebeldía. Ango Sakaguchi, uno de los buraiha, escribió un ensayo en 1946 en donde exponía algunas ideas sobre el sentido de la decadencia japonesa derivada de la derrota:

Luego de que la guerra terminara, nuestra libertad fue reconstruida, pero cuando esa libertad regresó empezamos a notar nuestras propias limitaciones y el modo en que incidían en nuestra libertad. La raza humana no puede vivir en eterna 
libertad. La razón es simplemente que vivimos, morimos y pensamos [...] La humanidad no cambia. Simplemente regresamos a ser humanos. La humanidad caerá en la decadencia. (Sakaguchi, 2012, p. 16)

Al igual que con el concepto de autoficción, Solano estructura su relato con puentes que se conectan con los escritores de la escuela buraiha. Pero dicha conexión no se refiere a una simple filiación entre un escritor colombiano en su aparente admiración y deseo de emular la vida y literatura de estos autores, sino que busca llevar al lector al sentido que en el presente tiene la decadencia. Solano parecería apuntar a una conclusión a través del diálogo que entabla entre su narrador-escritor con la escuela buraiha y su deseada complicidad con el detective coreano, donde el mundo actual en que se mueve su protagonista heredero de ambas situaciones, la posguerra y la Guerra Fría, no puede explicarse únicamente con los mismos mecanismos decadentes de los buraiha. De manera menos apasionada, pero quizá igualmente demoledora, Solano representa la deriva existencial del mundo contemporáneo, en especial el de la pérdida de identidad que amenaza a los migrantes de nuestros tiempos, como ocurre con el propio escritor colombiano. En muchos sentidos, el cuento de Solano hace eco de la paradoja que encierra para muchos las posibilidades abiertas por la globalización actual que, como García Canclini explica, oscilan entre los relatos de la apertura de fronteras, la comunicación entre diferentes pueblos y las relaciones sociales supranacionales, así como los "relatos de desgarramientos y conflictos, fronteras que se renuevan y anhelos de restaurar unidades nacionales, étnicas o familiares perdidas: intensidad y memoria" (García Canclini, 1999, p. 34). El narrador de "Manos de diamante" transita de la intensidad de su fascinación por los buraiha y por el detective coreano a la duda de reconocerse a sí mismo como sujeto o como simple personaje de una ficción ajena, como veremos más adelante.

\section{El grupo buraiha o escuela de la decadencia}

Joseph K. Yamagiwa (1906-1968) fue uno de los primeros críticos que habló en Occidente de los escritores que luego se conocerían como el grupo buraiha o escuela de la decadencia, de los cuales fue contemporáneo. En su artículo sobre la ficción en el Japón de la posguerra, el académico de la Universidad de Michigan clasifica a seis escritores bajo la denominación de escuela de la caricatura: "The Gisakuha or school caricaturing the intellectual classes' is 
represented by Tamura, Sakaguchi, Dazai Osamu, Takami Jun, Oda Sakunosuke, and Ishikawa Jun" (Yamagiwa, 1953, p. 15). A mediados del siguiente año, elimina a Taijirō Tamura del grupo — quien no reaparecería entre los buraiha-; el crítico precisa:

[...] in this literature we find pictures of the physical destruction and moral disintegration which World War II brought to Japan. A higher place in literature should be given to the Gisakuha or School of Caricature. Dazai Osamu, Sakaguchi Ango, Oda Sakunosuke, and Takami Jun are the principal members of this grupe. (Yamagiwa, 1955, p. 89)

En esa misma década, Ryôtaro Kato, en un artículo publicado por la Universidad de Oklahoma, se refiere también al estilo de dichos escritores de la posguerra que caricaturizan la sociedad como respuesta a la realidad de su momento, aunque sin establecer ninguna denominación para el grupo:

They wanted to make a fresh start, but were quite at a loss how and where to begin it. The guiding principles of life were gone, leaving everything looking wasted, futile, and hollow. Exactly in such a mood as this, Sakunosuke Oda and Osamu Dazai poured forth their caricatured pictures of man, coloring them with their peculiar irony and self-mockery. They scribbled at an amazing speed as if vomiting from nausea. Their activities were short-lived, as the former died of a sudden disease and the latter killed himself. Their works, which morbidly mirrored the confusion and blank despair of the period, had a great appeal to the readers of that time. (Kato, 1954, p. 295)

Yamagiwa se muestra inseguro de que los escritores de su denominada Gisakuha realmente pertenezcan al mismo grupo:

The exact classification of some of our authors may thus be open to question. I am least sure of the specific tendencies exhibited by the writers of the Gisakuha or School of Caricature and by some of the writers who have gained prominence in the post-war period. (Yamagiwa, 1953, p. 19)

La duda se justifica por la cercanía temporal del crítico a los que serían los tres autores principales de la escuela buraiha. Sakunosuke Oda había muerto en 1947 de una hemorragia por tuberculosis a los 34 años, Osamu Dazai se suicidaría en 1948 a los 39 años, y Ango Sakaguchi moriría en 1955, a causa de un aneurisma cerebral a los 48 años. El mérito de ambos académicos, Jo- 
seph K. Yamagiwa y Ryôtaro Kato, fue presentar tempranamente en Estados Unidos a esos escritores que habían sido censurados y repudiados por ciertos sectores del Japón en su momento.

Otro nombre con el que la crítica japonesa llamó a ese movimiento literario de la posguerra fue shingesakuha, término que se tradujo en general como nueva ficción:

Shingesakuha, 'new fiction' movement, harking back to the genre of the Tokugawa period (gesaku bungaku) that had sought to make respectable a lighter literary genre in an atmosphere dominated by weighty Confucian didactic novels. (Wolfe, 1990, p. 87)

Pero no se trataba solo de un nuevo estilo de ficción, sino que específicamente se refería a "the new gesaku writers" (Keene, 1984, p. 1022; Sas, 1998, p. 43), género incluido en la misma cita de Wolfe. García Parra (1986, p. 351) subraya en su reseña a los dos volúmenes de la obra de Keene, que la escuela buraiha "reacciona contra la shirakaba y busca el rescate de la vieja escuela gesaku".

Donald Keene (1984, p. 11), en su clásico estudio, hace referencia a la literatura japonesa a partir de 1853: "the gesaku (playful) writings that had flourished since the end of the eighteenth century had dropped to an abysmal level”. Al estilo informal de escritura se le llamaba gesaku (歔作), comprendía géneros narrativos basados en la cultura popular así como también libros de cómics (Falero, 2015, p. 548). Era una forma de escritura marcada por la censura, de manera que se buscaban estrategias discursivas para evadirla: "earlier gesaku writers had clothed their otherwise grotesque or indecent novels in the trappings of the conventional morality in order to escape rebuke from the censors" (Keene, 1984, p. 11). A finales de siglo XIX, prácticamente había desaparecido: "with rare exceptions, the later gesaku writers had nothing to say” (Keene, 1984, p. 14).

El término shingesakuha fue ideado por Oda Sakunosuke para referirse más positivamente a escritores del periodo de posguerra que, como él mismo,

5. La escuela shirakaba nació de una revista de 1910: "In April 1910 a group of young men who had been students at the Peers' School founded a journal called Shirakaba (White Birches). They were all of the upper class-either members of the old Kyoto nobility or samurai aristocracy, or else the sons of senior government officials. [...] In 1918, at the height of the popularity of Shirakaba, the members published an anthology of their works, each man choosing the story or poems by which he wished to be remembered" (Keene, 1984, pp. 441-442). 
sentían que estaban desarrollando una literatura renovada y vital, en oposición a los movimientos literarios "dominantes" (Wolfe, 1990, p. 87). Andrés Felipe Solano incluirá a Sakunosuke en su cuento, "[u]na de las cabezas de esta 'escuela de la decadencia' fue Sakunosuke Oda” (p. 20), pero bajo el término buraiha. La denominación de shingesakuha presumiblemente incluiría a más escritores que la de buraiha. Sin embargo, el término shingesakuha terminó como sinónimo de buraiha, denominando la prosa satírica - no siempre humorista - de los escritores de esa escuela: "Buraiha writers are known for their subversive, satirical prose for which they are called shingesaku-ha (School of New Gesaku), after the Edo comic literary tradition" (Yiu, 2010, p. 141). Keene recoge la historia del nombre de ese grupo de escritores que, en sentido estricto, nunca llegaron a establecer una relación tan cercana entre sí.

El término con el que se les conoce hoy en día, burai-ha (escuela burai), tiene su origen en tiempos remotos:

The term "burai" has been painstakingly traced back to the history, Shih Chi, of Ssu-ma Ch'ien, written in the second century B. C. In a passage describing the ceremonies that marked the completion of the Wei Yang Palace of Emperor Han Kao-Tsu, the emperor related that as a youth he had been burai- that is, he had been incompetent to deal with family business and had shown himself to be far less diligent than his brothers. (Keene, 1984, p. 1023)

La falta - o aparente falta - de propósito, la tendencia a beber y su vida desordenada caracterizaron de manera similar a los escritores de este grupo de posguerra como burai. Pero no se debe olvidar que el espíritu de rebeldía contra las tendencias dominantes, tanto en la sociedad como en el ámbito literario, fue otro atributo esencial de los buraiha ya considerados como escuela; en el cuento, se resume su caracterización en tres términos: "los decadentes, los disolutos, los libertinos de la literatura japonesa" (p. 20). Keene (1984, p. 1023) señala que el primero que usó ese nombre había sido el propio Osamu Dazai, en mayo de 1946, con toda ironía en su respuesta a la crítica de Kishi Yamaji. Pero le imprimió un matiz particular que permanecería para el grupo: "Dazai's use of this term buraiha to which he gives a French pronunciation (libertin) and a contemporary Japanese significance" (Wolfe, 1990, p. 88). El neologismo de Dazai sería aceptado de forma definitiva en la literatura japonesa gracias a Okuno Takeo, quien lo incorpora en su libro de 
1966. ${ }^{6}$ Ángela Yiu consigna los nombres de los escritores considerados como los más representativos del grupo buraiha, agregando las primeras obras que los distinguieron:

\begin{abstract}
Representative works include Sakaguchi Ango's Darakuron (On Decadence, 1946), Dazai Osamu's Shayō (The Setting Sun, 1947 [1968]), Oda Sakuno-Suke's Sesō (The State of the Times, 1946 [1990]), and Ishikawa Jun's Ōgon densetsu (The Legend of Gold, 1946 [1998]). Perhaps more than any other writers, Buraiha authors defined the spirit of defiance and skepticism in the postwar period. (Yiu, 2010, p. 141)
\end{abstract}

La mayoría de los críticos centró su atención en Osamu Dazai. Inclusive Okuno Takeo, que está considerado como el crítico por excelencia de los buraiha en los años sesenta, dedica su obra al escritor suicida: Dazai Osamu ron: Ketteiban (1966). El único escritor estudiado y traducido al inglés y al español en el siglo XX sería Dazai, al cual se consagrarían también amplios estudios, como el capítulo 25 del libro de Donald Keene, "Dazai Osamu and the Burai-ha" (1984) y el libro de Alan Stephen Wolfe, Suicidal Narrative in Modern Japan: The Case of Dazai Osamu (1990). Joseph K. Yamagiwa (1953, p. 15) afirmaba desde los años cincuenta: "Dazai, perhaps the most gifted writer of this school, was one of the participants in a double suicide in 1948". Afirmación que se ha mantenido vigente hasta el siglo XXI: "Dazai was, and still is, the most popular among the Buraiha writers" (Sakakibara, 2003, p. 191).

\title{
La proyección editorial de los buraiha en Occidente
}

La página web GetTextbooks-Japan (2021) registra como primera traducción al inglés The Setting Sun, de Osamu Dazai, por Donald Keene (1968, New Directions). El mismo Keene traduciría No Longer Human, también de Dazai, en 1973 y en la misma editorial. En español, la primera en publicar a uno de los buraiha fue la editorial Kaicron en Buenos Aires: Osamu Dazai, Corre Melos y otros relatos, 2000, seguida por la editorial vasca Txalaparta en 2004, El ocaso de Osamu Dazai, en cuya introducción se le equipara con Dostoievski (Watkins, 2004, p. 8). Sajalin, editorial independiente de Barcelona, es la que

6. "The definitive acceptance of the term buraiha in literary circles is considered to have occurred when the dean of Buraiha critics Okuno Takeo used it as a chapter heading ('Buraiha no bungaku') in his Dazai Osamu ron. In 1967, Okuno jokingly disclaimed credit for this honor, suggesting that he merely made use of the term since it was already in circulation in the early 1950s" (Wolfe, 1990, p. 234). 
más ha publicado obras de Dazai: Indigno de ser humano, Ocho escenas de Tokio, Repudiados y El declive, en 2010, 2013, 2016 y 2017, respectivamente. La página donde se reseña la novena edición de Indigno de ser humano cierra con el conocido elogio de Yukio Mishima: "Dazai fue un escritor que se esforzó en exponer precisamente lo que yo más quería ocultarme a mí mismo" (Sajalín, 2020). A partir de 2010, se da un asombroso incremento de reediciones en japonés y de traducciones en español de las obras de Dazai. Satori, especializada en cultura y literatura japonesa, publica Recuerdos en 2012 y Cuentos de cabecera en 2013. Esta misma editorial asturiana imprimiría la única obra de Ango Sakaguchi que se consigue en español, En el bosque, bajo los cerezos en flor, en 2014. La editorial madrileña Impedimenta publica Colegiala, en 2013; la catalana Candaya, La felicidad de la familia, también de Osamu Dazai, en 2017. Quaterni, de Madrid, ha publicado tres antologías (2013, 2016 y 2020) que incluyen a Dazai y, dos de ellas, a Ryūnosuke Akutagawa, el maestro que ejerció mayor influencia en el buraiha suicida. Cabe destacar que en el cuento habría también un homenaje a este escritor. La caracterización del protagonista, Park Bong, se equipara con el actor de la famosa producción cinematográfica Rashomon (1950), de Akira Kurosawa; obra maestra basada en el cuento de Akutagawa que influyó de forma decisiva en la obra de Osamu Dazai, el buraiha más reconocido: "Era como si el gran Toshiro Mifune hubiera salido de una pantalla de cine y me hubiera hablado. [...] Sus cejas y su quijada eran las mismas" (p. 21).

La antología de 2016 incorpora a Ango Sakaguchi y, por primera vez en español, a Oda Sakunosuke junto a una decena más de narradores contemporáneos. Hubo que esperar hasta el siglo XXI para que las editoriales internacionales se fijaran en el resto de los miembros. No obstante, hasta la fecha, Jun Ishikawa no cuenta con ninguna traducción al español; junto con Ango Sakaguchi, han sido más favorecidos por el mercado editorial en lengua francesa e inglesa. ${ }^{7}$

Silenciados durante más de una década y etiquetados como un grupo de escritores disolutos y renegados, los buraiha representaron la falta de rumbo

7. El mayor interés en Francia por los textos de Ishikawa podría deberse a su formación como universitario: "As students, Ishikawa Jun (1899-1987) and his friends from the French Literature Department of Tokyo Gaikokugo Gakkō, whose illustrious alumni included Nagai Kafū, Futabatei Shimei, and the anarchist Ŏsugi Sakae, received their issues of La Nouvelle Revue Française at the Maruzen bookstore" (Sas, 1998, p. 36). 
y la crisis de identidad de una nación a la deriva (Orbaugh, 2003, p. 57). ${ }^{8} \mathrm{La}$ promulgación de una Constitución al estilo americano había ampliado sin precedentes las libertades del pueblo japonés. Sharalyn Orbaugh (2003, p. 57) señala que en ese contexto la literatura renació, escritores e intelectuales fueron libres de expresarse sin temor a sanciones o represalias. ${ }^{9}$ Escribieron sobre la guerra y el caos de la posguerra. Sin embargo, reinaba el individualismo. Richi Sakakibara amplía sobre el último aspecto:

In the midst of this chaos, a group of young writers called the Buraiha (Decadent School) became very popular. Unlike the Shirakaba School, whose members identified themselves as a literary circle, Buraiha writers never actively started a literary movement. In this sense, the success of the Buraiha was not strictly a literary phenomenon. Rather, it reflected the historical circumstances of the contemporaneous Japanese readership, which needed to establish new social norms and moral criteria through reading and discussing Buraiha works. (2003, pp. 190-191)

Desde los años ochenta, Keene afirmaba sobre los pocos lazos que existían entre ellos:

Although these men (plus a few others) are often described as if they formed a closely knit group, few ties bound the members. They did not even publish a little magazine [...]. The burai-ha was less a group linked by common backgrounds or aims than a number of independent writers who happened to possess similar tastes, and who were regarded by the rest of the literary world as being somehow related. (1984, p. 1025)

Ese sería un punto en común entre los buraiha y la generación Granta de la que procede Solano. Las obras y los mundos de los escritores buraiha están poblados de seres marginados, forajidos, desertores y fracasados, los tradi-

8. Miriam Kingsberg (2013, p. 144) afirma con base en varios estudios: "In 1952, [...] stimulants initially attracted prominent figures in the postwar creative world, including [...] writers Dazai Osamu, Sakaguchi Ango, Tanaka Hidemitsu, and Oda Sakunosuke”.

9. Sobre el estado de la literatura antes de la Segunda Guerra Mundial, Yamagiwa (1953, p. 3) señala: "Proletarian literature, which had seen a spectacular rise after World War I, declined rapidly after the death of the leftist writer, Kobayashi Takiji, in a police station at Tsukiji, Tokyo, on February 20, 1933. Writers previously devoted to liberal, progressive, and radical ideas were converted to orthodox thinking. In the late thirties and during World War II the few authors who still nurtured leftist ideas were completely silenced. Some, like Hirabayashi Taiko, went to jail". 
cionalmente débiles u oprimidos, desde mujeres y niños hasta enfermos, lisiados o mentalmente deficientes. Las acciones y pensamientos de estos personajes contrastan con otra realidad, el mundo de lo normal, lo sano, cuerdo, fuerte y exitoso (Wolfe, 1990, p. 88). Pero Wolfe destaca que no había ningún esfuerzo en estas obras por forjar vínculos con una clase trabajadora militante y en ascenso. Los mundos descritos por los escritores buraiha estaban completamente desprovistos de tales presencias: no había una lucha de clases aparente (Wolfe, 1990, pp. 87-88). Por lo tanto, concluye, debían ser considerados rebeldes: "If their actions and behavior cannot be termed revolutionary, they can and are considered rebellious" (Wolfe, 1990, p. 88).

En marzo de 1946, Osamu Dazai — cuyo verdadero nombre era Shūji Tsushima- publicaría su manifiesto: "I'm a libertine (buraiha). I rebel against constraints. I jeer at the opportunists" (Wolfe, 1990, p. 88). Dazai sintió el deseo de convertirse en escritor desde el bachillerato. Adoraba a Ryūnosuke Akutagawa y su suicidio en 1927 lo sumió en una crisis que lo llevaría a considerarse burai. Se imaginaba a sí mismo como un discípulo secreto de Akutagawa. De todos los predecesores de Dazai, el autor de Rashōmon sería el más influyente en los escritos del también suicida (Chia, 1988, p. 6). ${ }^{10}$

Si bien los buraiha compartían la estética de "la decadencia", Ango Sakaguchi se decantó por la escritura que seguía ciertos principios budistas:

A scholar of Sanskrit, Pali, and Tibetan, which he studied to further his readings in Buddhist scripture, Sakaguchi juxtaposed a longing for $m u$ (nothingness) and a great appetite for life; stoicism and carnal desire; open-mindedness and criticism of the morality and values of the times. (Lowitz, 1995, p. 52)

Ango Sakaguchi (1906-1955) escribió varios ensayos provocativos sobre el concepto de daraku (decadencia), Darakuron (On Decadence) y Zoku Darakuron (More Thoughts on Decadence), ambos publicados en 1946. Exploró la idea de daraku, particularmente en lo que se refería a la posibilidad de una subjetividad remodelada frente a los temas de ilusión y desilusión: "The radical and modernist, and possibly postmodernist, aspects of Ango's work, these themes lend it an unmistakeably Buddhist flavor" (Shields, 2011, p. 226). Cuando los

10. Numerosas traducciones incluyen a ambos escritores, como en Akutagawa and Dazai. Instances of Literary Adaptation (2004). En español, Ryunosuke Akutagawa, Osamu Dazai y Kenji Miyazawa, Antología de relatos japoneses. Tres maestros de la literatura (Quaterni 2014); Akutagawa y Dazai en Un gran descubrimiento (2015), Relatos de gatos (2018) y Relatos de perros (2020). 
dos ensayos de posguerra sobre la decadencia se leen junto con las reflexiones de Sakaguchi sobre la cultura japonesa durante la guerra (Nihon bunka shikan, 1942), forman la base de lo que Shields llama "a post-metaphysical Buddhist critique of culture" (2011, p. 227).

Por su parte, Oda Sakunosuke (1913-1947) marcó un diferente camino al centrar su escritura en la cultura popular, las costumbres y el lenguaje de Osaka, su ciudad de origen. Meoto Zenzai, escrita en el dialecto de Osaka, fue llevada al cine en 1955 (Filmaffinity, 2021). La Universidad de Columbia publicó en inglés, por primera vez, una obra de Sakunosuke, Stories of Osaka Life, en traducción de Burton Watson, 1990. ${ }^{11}$ Dicha traducción se reeditó en 1994, dentro de la Unesco Collection of Representative Works, Japanese Series. La editorial También El Caracol con sede en Buenos Aires, que dedica la colección "Bosque de bambú" a la literatura japonesa, publicó El signo de los tiempos de Oda Sakunosuke, en 2020. Donald Keene (1984, p. 1025) había afirmado que la obra de este escritor no tenía tanta importancia: "Oda Sakunosuke, a lesser writer, is remembered more for his short, chaotic life than for his works, though a few stories that describe life in the lower classes of Osaka are still read", y que era poco probable que en el futuro se rescataran sus textos:

For a time, especially during the years immediately after the war, his writings enjoyed considerable popularity, and he wrote prolifically in response to the demand for manuscripts, but most of his hastily composed manuscripts have been forgotten, and it seems unlikely that he will be rediscovered by a new generation. (Keene, 1984, p. 1081) 12 $^{2}$

Watson, en Stories of Osaka Life, contradice la predicción de Keene (Orbaugh, 1992, p. 69).${ }^{13}$ En su reseña, Sharalyn Orbaugh incluye parte del prólogo a la

11. Burton Watson (1925-2017) residió en Japón desde 1973 hasta su muerte: “Watson, whose spare, limpid translations, with erudite introductions, opened up the world of classical Japanese and Chinese literature to generations of English-speaking readers, died on April 1 in Kamagaya, Japan" (Grimes, 2017).

12. Keene agrega el dato de cómo se dio el encuentro entre los tres miembros principales de la escuela buraiha: "Oda Sakunosuke was closely associated with the burai-ha, especially during the last years of his brief life. He would meet Dazai Osamu and Sakaguchi Ango at bars in Tokyo" (1984, p. 1081).

13. Tesis doctorales de prestigadas universidades están dedicadas a las obras de Oda Sakunosuke: J. Shields, Down to Earth: Literary History and the Case of Oda Sakunosuke of Osaka (Princeton University, 1988); M. P. Cronin, Treasonous City: Osaka in the Japanese National Imaginary (University of California Irvin, 2010); M. T. Fargo, Makino Shinichi, Sakaguchi Ango, and Oda Sakunosuke: Modern Japanese Literature as a Joke (University of California Berkeley, 2011). 
traducción de Watson donde se sumaron Meoto Zenzai, Roppakukinsei, Sesō y Ki no Miyako de Sakunosuke Oda:

Oda saw himself as a shin-gesaku or new gesaku-style writer, carrying on this tradition of defiance, thumbing his nose at ideologues and arbiters of public morality alike. For this reason, he deliberately chose to focus upon society's bunglers and misfits, those who because of some flaw in their background or some unconventional turn of behavior are fated to endure loneliness, frustration, or ostracism (p. xv). (Orbaugh, 1992, p. 70)

Como Dazai, Oda publicaría también un ensayo que se leyó como una especie de manifiesto:

Oda Sakunosuke, leader of the so-called dekadan ha [the Decadents], challenged the authority of the old order by proclaiming in his famous essay "Kanōsei no Bungaku [Literature of Possibility]" (December, 1946) the necessity and the importance of the "naked body" which had "taken off the veil of morality, humanism, and other abstract ideas". (Kamei, 1981, p. 122)

Kyong-Hwan Oh, acerca de la "Literatura de las posibilidades" de Oda, señala que en dicha propuesta la historia está en conflicto con la realidad. Si la conciencia del perdedor lo obliga a encarnarse, los personajes representados por la mente maestra del artista intentarán conquistar la realidad. Incluso si experimentaran la derrota frente a la realidad, sus vidas no perderían la voluntad de conquista y asumirían la prueba de buscar una autocomplementación con la realidad. Tal diferencia hizo que Sakunosuke Oda inventara una forma diferente a la de la ficción tradicional (Oh, 2008, p. 296). Así, Oda:

[...] established himself as the premier author of modern Osaka, producing stories marked by extreme locality (of language, setting and sensibility) at a historical moment when that city's subordination to the capital Tokyo was being completed and confirmed. (Cronin, 2013, p. 67)

Su escritura representa una alternativa: un cosmopolitismo arraigado en una Osaka local y excéntrica:

The latter vision is not innocent of imperial ambitions, but it does demonstrate the potential to betray a misconception fundamental to empire. By locating that vision in Osaka, Oda suggests that city's unique potential. (Cronin, 2013, p. 82) 
Juan F. Comperatore (2020) habla del "exquisito convite de la literatura de un escritor ignoto en estas tierras. Entre los muchos motivos que existen para leer a Oda no es menor que nos permita rehuir de la mirada exotista y otear un Japón con lentes nuevos". Y agrega comparando con la pureza y elegancia que se exhibe en la obra de Yasunari Kawabata, "las geishas de Oda lucen el maquillaje descorrido y su aliento fétido huele a alcohol, si describe su kimono es porque muestra más que lo que oculta" (Comperatore, 2020). Finalmente, una de las reseñas más tempranas se destaca por la inclusión del término que denomina el particular estilo de la escritura de Oda Sakunosuke: "la afinidad por lo grotesco y lo erótico - lo grótico, como bautizó su mujer a los productos de su pulsión creadora-" (Crespo, 2020). La reseña concluye afirmando que Oda fue "un conocedor afilado de las tradiciones literarias de su país y su provincia. La mezcla entre vanguardia y raigambre hizo de él un esteta irredento que escribió desde un yo más preocupado por observar que por observarse" (Crespo, 2020).

Tanto Osamu Dazai como Sakunosuke Oda son dos escritores buraiha que se relacionan directamente y a veces de manera no tan explícita con "Manos de diamante" de Andrés Felipe Solano, según veremos en los siguientes apartados.

\section{El yo autoficcional tendiendo puentes}

Manuel Alberca propone que la autoficción representa un pacto ambiguo de lectura en la intersección de los elementos autobiográficos del autor, que se insertan en el relato a partir de la identidad nominal, y los elementos ficcionales que le otorgan movilidad a la trama a partir de estrategias literarias, como el desarrollo y clímax dramático:

En resumen, la autoficción pretende romper los esquemas receptivos del lector (o al menos hacerle vacilar), al proponerle un tipo de lectura ambigua: si por una parte parece anunciarle un pacto novelesco, por otra, la identidad de autor, narrador y personaje le sugiere una lectura autobiográfica [...]. Pero sobre todo, y esto es para mí lo más importante por controvertido que pueda ser desde la poética del relato, permite precisar el gradualismo variable y complejo con que el lector tiene que descifrar en estos textos situados a caballo de los dos grandes pactos narrativos, el autobiográfico y el ficticio. A este escenario literario lo he llamado en otro lugar el "pacto ambiguo". (Alberca, 2006, p. 119) 
Indudablemente, cada autor decide el orden del entramado discursivo para acercar a su lector al pacto ambiguo que menciona Alberca. En el caso de "Manos de diamante", Solano comienza presentando el elemento novelesco del relato desde el presente enunciativo, el narrador-escritor recuerda el encuentro con el misterioso personaje Park Bong, el detective coreano:

Nos conocimos una noche hace siete años a bordo de un ferri que cubría la ruta entre Busan y Osaka y nunca volvimos a vernos. Aun así le debo todo lo que soy. Sin Park Bong todavía estaría tirado en la playa cerca del puerto a donde van los marineros rusos a pasar sus tardes libres. (p. 20)

De manera sutil, desde el inicio comienza a tender el puente, también marítimo, hacia Japón, que más adelante se dirigirá específicamente hacia los escritores de la escuela buraiha; pero más aún, introduce un elemento intrigante que hace girar la atención hacia el yo narrador cuando dice que le debe todo lo que es al personaje coreano.

Ya ubicado en el tiempo narrativo correspondiente al presente de la trama, el narrador desvela hasta qué punto la conexión con el grupo buraiha y con el detective se deben al azar y a la deriva en la que se encuentra, en el tiempo que precede al encuentro: "Mi esposa se había ganado un viaje a Osaka para dos en un sorteo de una compañía de teléfonos celulares. El premio no cubría el alojamiento ni la comida pero yo tenía un deseo imperioso de conocer aquella ciudad" (p. 20).

El azar del premio ganado por la esposa no se diferencia mucho del motivo que lleva al protagonista a tener ese "deseo imperioso" por conocer Osaka, ya que el interés por la ciudad se deriva de haber conocido, por azar también, a los escritores buraiha:

[Y] o vagabundeaba durante el verano por la playa con la excusa de estar recolectando información para una novela. En los meses fríos me refugiaba en una biblioteca pública. Fue en aquel lugar donde las ganas de ir a Osaka se incubaron en mí como la malaria. Una de esas tardes encontré una antología de ensayos en inglés sobre literatura japonesa. La mayoría eran aburridos salvo uno, que leí tres veces. Hablaba sobre la escuela de los buraiha. (p. 20)

El texto, desde este segundo párrafo, tiende ya el puente que unirá a su protagonista con una imagen autorreferencial, aún difusa pero ya presente como escritor en busca de alianzas intertextuales y experienciales con los 
buraiha. Así, cobran sentido los guiños anecdóticos que había mencionado el narrador-escritor, como el ambiente de puerto y la vida disoluta propicia en este entorno decadente:

Un parasol con varillas de metal oxidadas, una lata grande de cerveza, una caja de pollo frito y yo mirando a esos hombres, algunos panzones, otros con cuerpos llenos de cicatrices, la mayoría calvos. En mis recorridos por las cercanías del puerto había encontrado los restos de sus noches tirados al lado de las inmensas bodegas donde se almacena el pescado o amontonados frente al Billar Madonna o al Bar Lolita, donde se refugiaban aquellos marineros después de la caída del sol. (p. 20)

En su vagabundeo sin sentido, el protagonista vive ese ambiente que se corresponde con su referente real en el puerto de Busan del presente, al igual que encuentra el ambiente de los escritores malditos del Osaka del pasado leyendo un ensayo en una biblioteca a la que entra para refugiarse del frío:

"Un grupo de escritores que abrazaron el alcohol, las drogas, el sexo y una vida llena excesos como respuesta a la crisis de identidad que sufrió Japón durante y después de la Segunda Guerra Mundial", así los presentaba el autor al principio del ensayo. Los buraiha eran los disolutos, los rufianes, los libertinos de la literatura japonesa. (p. 20)

La conexión entre ambos espacios la construye el narrador-escritor para darle sentido a su relato, al mismo tiempo que aporta un significado para su yo protagonista. Como explica Musitano:

En las escrituras del yo se nos presenta una persona no tal como fue, sino como cree estar siendo en el pasado, desde el punto de vista de lo que imagina llegará a ser, o mejor, habrá sido cuando termine de escribir, cuando intervenga el lector. (2016, p. 115)

Llegado a este punto, con un toque de humor, el narrador intenta emular, o quizá parodiar, a los buraiha:

Una vez en Osaka tenía un plan muy simple, me llenaría la panza de alcohol en memoria de los buraiha y trataría de convencer a mi esposa de que hiciéramos un trío con una chica japonesa. Ese sería el homenaje más grande a la escuela de los decadentes. (p. 20) 
El narrador-protagonista está proyectando lo que será su yo, como personaje, cuando registre ese suceso que leerán sus lectores cuando termine el texto que está escribiendo, pero que finalmente no sucede en el relato:

Mis intenciones cambiaron tan pronto entré en contacto con Park Bong. Al final de la noche en que nos conocimos me convertí en un autor de novelas policiales. Hasta ahora he publicado un solo libro pero ha tenido gran éxito. Se llama Manos de diamante y su protagonista es un detective con una cara difícil de recordar. (p. 20)

Aunque el plan de experimentar la vida decadente de los buraiha se derrumba debido al encuentro con el detective coreano, no sucede igual con el puente que tendió ya en el relato entre su devenir y la relación que tiene con la escuela buraiha; por el contrario, se alza a un nivel metadiegético. La verosimilitud y las posibles lecturas del relato se deben precisamente al encuentro con el personaje coreano que dará sentido a la trama del cuento y a las resonancias que este suceso tiene en el pacto ambiguo autoficcional que finalmente propone el narrador-autor-protagonista. Por ejemplo, el hecho de que Solano en este cuento haga una proyección al futuro de la novela que publicaría en el 2016, Cementerios de neón, en parte inspirada por un agente coreano del Servicio de Inteligencia que trabajaba en Colombia en los años de la Guerra Fría encubierto como profesor de taekwondo. En nuestro relato, es el detective el que inspira su "futura" novela exitosa, pero se habla tangencialmente de aquel otro coreano, el que aparecerá en la novela de 2016:

- Soy de Colombia — respondí sin ganas, pensando que el hombre no tendría ni la más remota idea de dónde quedaba el país donde nací.

— ¡Ah, qué bien! Conozco a alguien que vive en Colombia. Tiene una academia de taekwondo. Su apellido es Moon... El maestro Moon. Pero en realidad se dedica a otra cosa, digamos que a un oficio un poco pasado de moda. (p. 20)

El maestro Moon se menciona también en su crónica Corea: apuntes desde la cuerda floja, publicada el mismo año de la primera versión en japonés e inglés del cuento que nos ocupa. Los paralelos son evidentes cuando leemos lo que Solano dice de este personaje a un amigo: "Le conté que había estado pensando en una idea para una novela sobre un coreano que conocí en Colombia, un hombre con mil vidas" (Solano, 2014b, p. 59); o más adelante, a una catedrática hispanista coreana: "Sin pudor le conté que me gustaría escribir una novela 
que incluyera a ese hombre, aquel profesor de taekwondo, y le pregunté si creía que habría problema en mencionar su doble vida" (2014b, p. 178). La lectura vacilante y creativa al mismo tiempo que provoca la autoficción oscila entre los polos autobiográficos y ficticios a lo largo del cuento. El narrador es un escritor colombiano que le debe todo a un personaje del cual le es imposible precisar su aspecto: "No es que haya olvidado su cara, es que su cara cambia a diario en mi cabeza. Es como lava de un volcán en constante erupción que no consigue una forma definitiva" (p. 20); de quien ni siquiera recuerda su nombre completo, Park Bong, del que como le dice su esposa, ese nombre es absurdo para un coreano; en fin, un personaje que no llega a tener asidero en la realidad. ${ }^{14}$ Por su lado, a pesar de que el narrador-protagonista explícitamente declara su nombre, Andrés, el detective, lo tergiversa y lo llama Andrea todo el tiempo. El narrador, en efecto, llega a escribir una novela que menciona en el cuento sobre un perfecto impostor como Park Bong, "que había trabajado en una dependencia de la Agencia de Seguridad Nacional de Corea" (p. 21), un hombre con mil vidas, como se dice del personaje Moon de Cementerios de neón.

El personaje del detective también acentúa la dualidad entre los dos mundos a partir de su caracterización como conocedor de la escuela buraiha, otra conexión con el mundo real del narrador, pero al mismo tiempo aparece en la trama como si fuera un personaje de alguna obra de los buraiha: un contrabandista, un detective privado, con una filia sexual excéntrica, asociado a los bajos fondos, bebedor, un decadente que deambula por "los burdeles de Texas Street en Busan [y] los de Tobita Sinchi en Osaka" (p. 23). En consecuencia, el escenario es el del autor-narrador conviviendo con su personaje perfecto en el texto que está escribiendo. Esta combinación de elementos, como dice Alberca, hace que "la inestabilidad referencial y enunciativa de la autoficción provo[que] una lectura oscilante entre los polos ficticio y autobiográfico, que rechaza la consideración meramente textual de la novela" (2006, p. 126). En esto consistiría la aceptación del pacto ambiguo por parte del lector, quien deberá darle sentido a todos los elementos puestos en escena en la autoficción.

14. El narrador-escritor relaciona el rostro de Park Bong con "el gran Toshiro Mifune" (p. 21). Mifune fue el célebre protagonista de la película Rashōmon (1950) dirigida por Akira Kurosawa sobre el cuento homónimo de Akutagawa (Sharp, 2020). 


\section{La vuelta al yo y la crisis identitaria}

Una virtud del cuento de Solano es la de dejar transitables los puentes que hemos mencionado para que el lector pueda circular por el relato en diferentes direcciones. Una de ellas, la que refiere al pacto ficcional, puede consumarse sin problemas alrededor de la figura novelesca del detective, un relato al estilo buraiha que presenta a ese personaje de los bajos fondos con una personalidad decadente, intrigante, que vive en unos márgenes de la sociedad por demás oscuros debido a su pasado y a su presente. Otra dirección para el lector podría decantarse hacia el pacto biográfico, como una apertura pública de algunos callejones que servirían de ruta en la aventura creativa de un autor, para ver cómo se construye la idea del relato, en este caso por el azar, dando esencia novelesca al propio proceso que emula al mismo relato. Un autor que acepta su identidad nominal para proponer que lo que escribe tiene asidero en la realidad, para el cual los detalles del mundo real — si podemos llamarlo así- están ahí para cautivar al lector. El texto está estructurado de tal forma que no traiciona ninguna de estas posibilidades, tampoco engaña porque no ofrece una verdad que necesite ser verificable para funcionar, sino que juega con el péndulo entre ambos espacios.

No obstante, aceptando esa premisa de que en un relato nada es fortuito, el cuento ofrece además la posibilidad de otras lecturas: las del pacto ambiguo, la lectura vacilante, para ver el sentido de la intersección de pilares narrativos que lleva a cabo Solano, una autoficción que se nutre del tema y la forma buraiha de la decadencia, para deconstruir el yo narrador-autor. Musitano, siguiendo a Duque-Estrada, explica:

La deconstrucción de la noción clásica del sujeto, a pesar de sus formas varias, tiene como horizonte la apertura para una comprensión de una subjetividad siempre en devenir, de procesos de subjetivación que no atienden a ninguna finalidad preconcebida porque ellas solo se procesan en el acontecer continuo y aleatorio de la propia vida. Así como se formula una deconstrucción de la noción de sujeto tradicional, esto afecta asimismo la noción de sujeto autobiográfico. (2016, p. 110)

Si decidimos abordar una lectura que vaya más allá de la bien elaborada trama de un cuento que apunta a la construcción de un personaje decadente y excéntrico, como es Park Bong en homenaje a la escuela buraiha, queda por explicitar cuál sería la relación profunda que este motivo literario supone para 
la cimentación del sentido del relato. Para ello, es preciso ir de la construcción del personaje Park Bong a la deconstrucción del yo narrador, Andrés. Lo anterior nos permite pensar en la escuela buraiha como un antecedente del relato, pero no como emulación literaria, sino como devenir de la crisis que los japoneses apuntaban a partir de la regularización de la derrota del espíritu humano después de la guerra. Dice Manuel Crespo sobre el término buraiha:

[...] remite a una escritura del fracaso y la alienación, repleta de personajes quebrados e irrecuperables, la supuesta baja estofa que menudea en los bajos fondos de las ciudades. Prostitutas, delincuentes, borrachos, vagabundos. Y, por supuesto, los escritores que narran sus vidas. (2020, énfasis nuestro)

Crespo agrega que, en El signo de los tiempos, Sakunosuke Oda "habla de la persecución que se entabla entre un escritor y sus temas, aunque no queda claro quién persigue a quién, y mucho menos si la cacería traerá algún resultado" (2020). Entonces, algunos detalles del cuento de Solano se vuelven más significativos, como que el narrador refiera de entre los autores japoneses en especial a Sakunosuke Oda. Gonzalo Gossweiler entrevista a Mariana Alonso, directora de la editorial independiente argentina También El Caracol, quien destaca sobre la traducción de El signo de los tiempos lo siguiente:

Acabamos de terminar la traducción de un autor de Osaka, que usa el dialecto de la región de Kansai. Es, además, un autor cuya literatura es muy autobiográfica, hay muchas referencias a su ciudad, a otros autores y a circunstancias muy particulares de su época que requirieron investigación. Se llama Oda Sakunosuke. Odasaku, le decían los amigos. (Gossweiler, 2019)

El narrador-protagonista del cuento de Solano afirma: "Tenía en mente escribir una novela corta y afilada al mejor estilo de los buraiha" (p. 20). Para ello, escoge a "Oda y su relación con Osaka" (p. 20), con lo cual queda de manifiesto su relación con dicho escritor y su poética.

La contracubierta de El signo de los tiempos (Oda, 2020) dice: "Buscando el suyo, Oda nos abre un camino. El del buraiha entregado, el del shin gesa$k u$ que no entrega sus banderas. Oda está en los márgenes del Japón de su tiempo, en el borde". La publicación atrajo numerosas y positivas reseñas. En una se compara la visión de Oda con la de Walter Benjamin, al señalar que los personajes de los relatos del escritor buraiha "se exponen como aquellos pedazos marginados por un orden temporal que los arrincona y les da forma 
[...]: personajes errantes que se construyen en clase residual — signo del progreso benjaminiano- para contar algunas historia de los derrotados" (Tripodi, 2020, p. 10).

El final del relato en muchos sentidos cuenta una historia de los derrotados, un narrador-protagonista que sucumbe a una desintegración de su yo cuando dice: "A lo mejor Park Bong es un escritor, un verdadero escritor, el último de los buraiha, y yo estoy en una de sus historias. A lo mejor él también intenta recordar mi cara en vano" (p. 23). Su devenir como sujeto queda cifrado por la incertidumbre que encierra esa locución adverbial de posibilidad, una posibilidad sin resolución en el relato, donde el narrador incluso cede su lugar como posible autor-sujeto de su historia. De manera cinematográfica en el último momento, los lectores pueden ver la serie de escenas que le dan sentido a esa construcción final de la derrota del sujeto: el narrador-escritor vagabundeando por Busan como excusa para una novela que no escribe, la desconexión con el mundo cotidiano, inclusive con su mujer, el proyecto trunco de emular a los buraiha en Osaka, la deriva en la que transcurre su viaje en barco sin que en el cuento llegue realmente a pisar el destino deseado. Especialmente significativa es la escena en la que debido a su condición como migrante colombiano es detenido en la aduana de Japón:

Duré casi una hora en pasar por inmigración a causa de mi pasaporte. Los agentes aduaneros estaban convencidos de que venía cargado de droga. Revisaron mi maleta varias veces. Sacaron mi champú y lo pusieron en una máquina de rayos X. Me mostraron algo parecido a un catálogo de compras pero en lugar de zapatos, joyas y perfumes había fotos de armas automáticas, bolsas con pastillas, un grueso fajo de dinero y una montañita de polvo blanco. Me preguntaron si llevaba conmigo alguna de esas cosas. Después me hicieron desvestir en un cuarto. Al final se disculparon. A la salida del terminal no había nadie. (p. 23)

La inspección como si fuera un narcotraficante le hace perder la oportunidad de encontrarse con Park Bong, a quien no vuelve a ver jamás. Sin embargo, si se aceptara que esta condición marginal pudiera acercarlo a acceder al grupo de los rebeldes buraiha, casi al final se revela que en la actualidad ha accedido a una posición pequeño burguesa que le ofrece tranquilidad económica, pero que anticipa su derrota como sujeto-autor que reconoce al final del cuento:

Mencioné que ayer me acordé de nuevo de Park Bong después de terminar de leer un cuento tirado sobre mi sofá de cuero, frente a un gran ventanal desde 
donde puedo ver el mar que separa a Corea de Japón. Al cerrar el libro sus rasgos volvieron a mí otra vez bajo la cara perfecta de un actor veterano o un santo, en todo caso alguien más allá del tiempo. Pero casi siempre su cara es una pizarra en blanco, un planeta vacío.

Mi esposa y yo no tenemos que preocuparnos tanto por el dinero. Las regalías de la novela siguen llegando a mi cuenta y un productor me contactó para una adaptación cinematográfica, pero de alguna manera estoy igual que al principio. Después de Manos de diamante no he podido escribir nada. (p. 23)

\section{A manera de conclusión}

Ango Sakaguchi, en su ensayo sobre la decadencia habla de las viudas de los soldados japoneses y de cómo llegaría una nueva etapa después de la guerra:

Después de todo, el día en que sus corazones le den la bienvenida al deseo de una nueva vida no está lejos. No ha sido la gente quien cambió. La gente es la misma como siempre lo ha sido. Lo que ha cambiado es la epidermis del signo de los tiempos. (Sakaguchi, 2012, p. 1)

El narrador-escritor, que a través de la construcción de su personaje buraiha, Park Bong, intenta autoconstruirse como sujeto en el relato, cree encontrar la clave de esa filiación en el motivo de la crisis de identidad de una generación a la deriva que va a contracorriente de un mundo que desesperadamente le da la bienvenida al deseo de una nueva vida y no a la decadencia. No obstante, la crisis del narrador-autor responde a una realidad del signo de los tiempos distinta, su preocupación es la del migrante contemporáneo que si bien, gracias a las ventajas que ofrece la globalización actual, no puede dejar de sentir inquietud por la amenaza de la aculturación, de la pérdida de la identidad. En una videoentrevista publicada en 2020, Solano comenta que tomar la decisión de migrar a Corea le permitía escribir gracias al trabajo que tenía y al tiempo que esta situación le otorgaba, pero inmediatamente después señala:

[O]bviamente me preocupa estarme alejando de la vida que viví en Colombia, de las personas que conocí, de mi interés por el país [...] pero sí, me inquieta... $Y$ cuando menos una vez al mes en el metro cuando estoy rodeado de coreanos digo, bueno yo qué estoy haciendo acá [...] además porque yo no hablo coreano [...], y ese es un temor también, si aprendo coreano quizá me quede para toda la vida acá, o lo contrario, o resulte expulsado al año y diga yo no quiero vivir en este país entre coreanos. (Patiño, 2020) 
Finalmente, podemos ver que la crisis del narrador-protagonista que busca su filiación con los buraiha para construirse como sujeto narrativo se percata de su fracaso, ya que los signos de su tiempo son otros, un tiempo que si bien es heredero del que enfrentaron los escritores japoneses y ante el cual ellos igualmente fracasaron en su intento por crear a partir de la decadencia un mundo renovado en la posguerra, es definitivamente otro, signado por el corolario de la posguerra, de la Guerra Fría, del afán capitalista y el progreso económico, de la polarización aguda entre un norte y un sur global que alimenta las migraciones internacionales con reglas asimétricas en el ejercicio del poder. Un mundo que cada vez puede menos sostener las promesas de igualdad global y que, por el contrario, refuerza la vigilancia de sus fronteras, de la puesta al día de nacionalismos excluyentes; unos signos de los tiempos que incluso en este contexto todavía pueden ofrecer la posibilidad para unos pocos de que se cumpla el deseo de una nueva vida cómoda, aunque sea a costa de la desintegración del yo y la deriva identitaria.

\section{Referencias}

Alberca, M. (2006). ¿Existe la autoficción hispanoamericana? Cuadernos del CILHA, 7(7-8), 115-127. https://bdigital.uncu.edu.ar/app/ navegador/?idobjeto $=1095$

Chia, J. (1988). Dazai Osamu: Life and Art. National University of Singapore. Comperatore, J. F. (2020, junio 3). El signo de los tiempos. Sakunosuke Oda. El Diletante. http://eldiletante.net/trabajos/el-signo-de-los-tiempossakunosuke-oda

Crespo, M. (2020, abril 30). El signo de los tiempos. Sakunosuke Oda. Otra Parte. https://www.revistaotraparte.com/otras-literaturas/el-signo-delos-tiempos/

Cronin, M. P. (2013). City, empire and flow: Osaka and the Philippines in Oda Sakunosuke's Wagamachi. Japan Forum, 25(1), 67-86. https://doi.org/1 0.1080/09555803.2012.738697

Doubrovsky, S. (2001). Fils. Gallimard.

Falero, A. (2015). Hacia una historiografía literaria en Japón. En P. Aullón de Haro (Ed.), Historiografía y teoría de la historia del pensamiento, la literatura y el arte (pp. 525-565). Dykinson.

Filmaffinity. (2021). Meoto Zenzai. https://www.filmaffinity.com/ca/ film377873.html 
García Parra, P. (1986). Dawn to the West, Japanese Literature of the Modern Era by Donald Keen [Review]. Estudios de Asia y África, 21(2), 349352. https://estudiosdeasiayafrica.colmex.mx/index.php/eaa/article/ view/924

García Canclini, N. (1999). La globalización imaginada. Paidós.

GetTextbooks, Japan (2021). https://www.gettextbooks.jp/

Grimes, W. (2017, mayo 3). Burton Watson, 91, Influential Translator of Classical Asian Literature, Dies. The New York Times. https://www.nytimes. com/2017/05/03/books/burton-watson-dead-translator-of-japaneseand-chinese-literature.html

Gossweiler, G. (2019, noviembre 16). La cultura japonesa está llena de matices y de elementos que parecen incluso contradictorios. Ámbito. https:// www.ambito.com/espectaculos/literatura/la-cultura-japonesa-esta-llenamatices-y-elementos-que-parecen-incluso-contradictorios-n5065764

Kamei, S. (1981). The Kiss and Japanese Culture After World War II. Comparative Literature Studies, 18(2), 114-123. http://www.jstor.org/stable/40246247

Kato, R. (1954). Modern Japanese Literature. Books Abroad. An International Literary Quaterly, 28(3), 6 y 290-297. https://doi.org/10.2307/40095861

Keene, D. (1984). Dawn to the West, Japanese Literature of the Modern Era. Fiction. Holt-Rinehart and Winston.

Kingsberg, M. (2013). Methamphetamine Solution: Drugs and the Reconstruction of Nation in Postwar Japan. The Journal of Asian Studies, 72(1), 141-162. https://doi.org/10.1017/S0021911812001787

Lowitz, L. (1995). Towards a Literature of the Periphery. Mānoa. A Pacific Journal of International Writing, 7(1), 50-53.

Musitano, J. (2016). La autoficción: una aproximación teórica. Entre la retórica de la memoria y la escritura de recuerdos. Acta Literaria, 52, 103-123. http://dx.doi.org/10.4067/S0717-68482016000100006

Oda, S. (2020). El signo de los tiempos (M. Kano, M. Alonso y M. Worsnop, Trads.). También El Caracol.

Oh, K. H. (2008). A Study on 'Literature as a possibility' of Oda Sakunosuke. Japanese Cultural Studies, 27, 281-296. http://www.dbpia.co.kr/journal/ articleDetail?nodeId=NODE01035000

Orbaugh, S. (1992). Stories of Osaka Life, by Oda Sakunosuke [Review]. Journal of the Association of Teachers of Japanese, 26(1), 69-72. https:// doi.org/10.2307/489451 
Orbaugh, S. (2003). Part II. Japan. En J. S. Mostow (Ed.), The Columbia Companion to Modern East Asian Literature (pp. 19-284). Columbia University Press.

Patiño, J. (2020, mayo 5). “Escribir es mi gimnasio". Entrevista con Andrés Felipe Solano. Jairitoe. YouTube. https://www.youtube.com/watch?v=JQR82AVBlY

Sajalín Editores. (2020). Sajalín presenta. http://www.sajalineditores. $\mathrm{com} /$ ? $\mathrm{p}=$ libro\&l=2

Sakaguchi, A. (2012, octubre 24). La tesis decadente (J. A. Onís Conde Trad.). Tadaima, 1-17.

Sakakibara, R. (2003). Dazai Osamu, Sakaguchi Ango, and the Burai School. En S. Orbaugh (Ed.), Part II. Japan (pp. 190-192). En J. S. Mostow (Ed.), The Columbia Companion to Modern East Asian Literature. Columbia University Press.

Sas, M. (1998). Chambered Nautilus: The Fiction of Ishikawa Jun. The Journal of Japanese Studies, 24(1), 35-58. https://doi.org/10.2307/132938

Sharp, J. (2020, agosto 25). 70 Years of Rashomon. A New Look at Akira Kurosawa's Cinematic Milestone of Post-truth. British Film Institute. https://www.bfi.org.uk/features/rashomon-akira-kurosawa

Shields, J. M. (2011). Smashing the Mirror of Yamato: Sakaguchi Ango, Decadence and a (Post-metaphysical). Buddhist Critique of Culture. Japan Review, 23, 225-246. http://doi.org/10.15055/00000201

Solano, A. F. (2014a). Pig Skin. En Y. Igarashi (Ed.), Granta 127: Japan (pp. 157-172). Granta Books.

Solano, A. F. (2014b). Corea: apuntes desde la cuerda floja. Universidad Diego Portales.

Solano, A. F. (2015, febrero-marzo). Manos de diamante. Buen Salvaje, 2, 24-27.

Solano, A. F. (2016). Cementerios de neón. Tusquets-Planeta.

Solano, A. F. (2018). Manos de diamante. Universo Centro, 102, 20-23. https:// www.universocentro.com/NUMERO102/Manos-de-diamante.aspx

Solano, A. F. (2020). Los días de la fiebre: Corea del Sur, el país que desafió al virus. Planeta.

Tripodi, G. (2020, agosto 16). Leer y escribir a contrapelo. Perfil, 10-11.

Watkins, M. (2004). Introducción. En O. Dazai, El ocaso (pp. 7-9). Txalaparta.

Wolfe, A. S. (1990). Suicidal Narrative in Modern Japan: The Case of Dazai Osamu. Princeton University Press. 
Yamagiwa, J. K. (1953). Fiction in Post-War Japan. The Far Eastern Quarterly, 13(1), 3-22. https://doi.org/10.2307/2942366

Yamagiwa, J. K. (1955). The Old and New in Twentieth Century Japanese Literature. En H. Frenz \& G. L. Anderson (Eds.), Indiana University Conference on Oriental-Western Literary Relations (pp. 87-104). The University of North Carolina.

Yiu, A. (2010). Okuizumi Hikaru and the Mystery of War Memory. En D. Stahl \& M. Williams (Eds.), Imag(in)ing the War in Japan: Representing and Responding to Trauma in Postwar Literature and Film (pp. 137-159). Brill. 